\title{
A randomised controlled trial of management strategies for acute infective conjunctivitis in general practice
}

\author{
Hazel A Everitt, Paul S Little, Peter W F Smith
}

\begin{abstract}
Objective To assess different management strategies for acute infective conjunctivitis.

Design Open, factorial, randomised controlled trial.

Setting 30 general practices in southern England.

Participants 307 adults and children with acute infective conjunctivitis.

Intervention One of three antibiotic prescribing

strategies-immediate antibiotics (chloramphenicol eye drops; $\mathrm{n}=104$ ), no antibiotics (controls; $\mathrm{n}=94$ ), or delayed antibiotics $(\mathrm{n}=109)$; a patient information leaflet or not; and an eye swab or not.
\end{abstract}

Main outcome measures Severity of symptoms on days 1-3 after consultation, duration of symptoms, and belief in the effectiveness of antibiotics for eye infections.

Results Prescribing strategies did not affect the severity of symptoms but duration of moderate symptoms was less with antibiotics: no antibiotics (controls) 4.8 days, immediate antibiotics 3.3 days (risk ratio $0.7,95 \%$ confidence interval 0.6 to 0.8$)$, delayed antibiotics 3.9 days $(0.8,0.7$ to 0.9$)$. Compared with no initial offer of antibiotics, antibiotic use was higher in the immediate antibiotic group: controls 30\%, immediate antibiotics $99 \%$ (odds ratio 185.4, 23.9 to 1439.2 ), delayed antibiotics $53 \%$ (2.9, 1.4 to 5.7$)$, as was belief in the effectiveness of antibiotics: controls 47\%, immediate antibiotics $67 \%$ (odds ratio $2.4,1.1$ to 5.0 ), delayed antibiotics $55 \%$ (1.4, 0.7 to 3.0$)$, and intention to reattend for eye infections: controls $40 \%$, immediate antibiotics $68 \%(3.2,1.6$ to 6.4$)$, delayed antibiotics $41 \%$ (1.0, 0.5 to 2.0). A patient information leaflet or eye swab had no effect on the main outcomes. Reattendance within two weeks was less in the delayed compared with immediate antibiotic group: 0.3 (0.1 to 1.0$) v 0.7$ ( 0.3 to 1.6 ).

Conclusions Delayed prescribing of antibiotics is probably the most appropriate strategy for managing acute conjunctivitis in primary care. It reduces antibiotic use, shows no evidence of medicalisation, provides similar duration and severity of symptoms to immediate prescribing, and reduces reattendance for eye infections.

Trial registration Current Controlled Trials ISRCTN32956955.

\section{Introduction}

Acute infective conjunctivitis is a common presentation to general practice. ${ }^{1-3}$ Traditionally topical antibiotics are prescribed despite most cases being self limiting ${ }^{4}$ and probably only half seen in general practice having a bacterial cause. ${ }^{5-7}$ Prescribing antibiotics for minor self limiting illnesses has been discour- aged because of concerns over antibiotic resistance and medicalisation, ${ }^{89}$ yet such prescribing for conjunctivitis has remained high. ${ }^{10}$

Evidence is lacking, particularly in general practice, on the effectiveness of prescribing topical antibiotics for conjunctivitis. ${ }^{4}$ A recent study suggested little benefit from chloramphenicol eye drops for children in general practice: time to cure difference of 0.3 days $(\mathrm{P}=0.03)$ between groups from days 2-7 after consulting. ${ }^{11}$ Another study showed no benefit from topical fusidic acid on conjunctivitis in adults in general practice. ${ }^{12}$ An updated Cochrane review, including these studies, showed a marginal benefit from topical antibiotics: clinical remission on days 2-5 (relative risk 1.24, 99\% confidence interval 1.1 to 1.5 ). ${ }^{13}$

Assessment of a delayed prescribing strategy, ${ }^{14}$ as widely implemented for respiratory tract infections,${ }^{15}$ would be useful if antibiotics are not to be used immediately. Additionally, qualitative research suggests that an information leaflet is helpful to patients. ${ }^{16}$ Targeting treatment to those with bacterial infection may improve outcome but consensus is lacking on using eye swabs to guide treatment, and swabs have the potential disadvantage of further medicalising self limiting illnesses. ${ }^{14}$

We assessed the effect of different prescribing strategies for chloramphenicol eye drops, a patient information leaflet, and an eye swab in adults and children with acute infective conjunctivitis. The open trial design also enabled assessment of antibiotic use, patients' beliefs in the effectiveness of antibiotics, and intention to reattend for eye infections.

We hypothesised that compared with immediate prescribing of antibiotics, delayed prescribing or no offer of an initial prescription would result in similar severity and duration of symptoms, less antibiotic use, less belief in the effectiveness of antibiotics, and less intention to consult for eye infections in the future.

\section{Methods}

Between April 2001 and April 2005 general practitioners or practice nurses in 30 general practices in Hampshire, Wiltshire, and Dorset recruited patients aged 1 year or more (no upper age limit) presenting with acute infective conjunctivitis. Patients were excluded if they were aged less than 1 year (to avoid cases of ophthalmia neonatorum or blocked tear ducts), were systemically unwell and required oral antibiotics (for example, for concurrent chest infection), had had antibiotics in the previous two weeks, had chronic infective eye disease (for example, blepharitis), had had eye surgery in the past month, or were allergic to chloramphenicol.

Our trial was an open randomised controlled trial of $3 \times 2 \times 2$ factorial design. We randomised patients to one of three 


\section{Research}

treatments: immediate antibiotics (chloramphenicol eye drops every two hours for two days then four times daily), delayed antibiotics (prescription to be collected from the surgery at the parents' or patients' discretion after three days), and no antibiotics (controls). The groups were also randomised to receive a patient information leaflet or not, creating six groups. The leaflet included information on the basis of our previous qualitative research on the self management and clinical course of conjunctivitis. ${ }^{16}$ Each patient in the six groups was also randomised to provide an eye swab or not. Eye swabs were obtained for microbiological data and to assess the effect of performing the test on the outcome measures.

Randomisation was by the opening of a numbered sealed opaque envelope by the recuiting general practitioner or practice nurse. These were prepared weeks or months in advance at the study centre using random number tables. Block randomisation (blocks of 12) was used to ensure similar numbers in each group. The general practitioners and practice nurses were unaware of the block size and were provided with a small number of packs (two to five) at a time. They followed an information sheet to standardise the advice given to the randomisation groups.

\section{Outcome measures}

The primary outcome measures were duration of moderately bad symptoms (days when one or more symptoms scored moderately bad or worse), mean symptom severity score on days 1-3 after consulting for conjunctivitis, and belief in the effectiveness of antibiotics for eye infections (extremely or very effective in treating eye infections on a six point scale).

We obtained outcome data from patient completed diaries, based on validated diaries used in trials of minor illnesses in general practice. ${ }^{14}{ }^{17} 18$ Patients scored their symptoms for 14 days on a seven point scale from 0 for normal to 6 for as severe as it could be. Symptoms were based on previous qualitative work: red eye, eye discomfort, eye discharge during the day, waking with a sticky eye, eyelid swelling, altered vision, and how unwell patients felt. ${ }^{16}$ Patients also completed questions on other symptoms, antibiotic use, belief in the effectiveness of antibiotics, intention to reattend for eye infections, and personal details. The diaries were returned by post. We sent non-responders up to two reminders. We calcu- lated a deprivation score (index of multiple deprivation) by entering the participants' postcodes into www.neighbourhood.statistics.gov.uk/.

\section{Sample size and statistical analysis}

We determined that to achieve an $80 \%$ response rate for the diary we required a minimum sample size of 264 to detect a difference between the groups of one day of moderate symptoms, 0.33 mean symptom score, and 15 percentage points in belief in antibiotics (significance level 0.01 , power $80 \%$ ). We assumed no interaction between groups.

We analysed data on an intention to treat basis using Stata. To determine which symptoms contributed to the symptom severity score we used factor analysis; internal reliability of the score was assessed using Cronbach's $\alpha$. We used multiple linear regression for the symptom severity score, multiple Poisson regression for duration of moderate symptoms, and multiple logistic regression for belief in antibiotics. We explored interactions between the intervention variables and potential confounders.

\section{Results}

Between April 2001 and April 2005, 38 general practitioners and practice nurses in 30 general practices in Hampshire, Wiltshire, and Dorset recruited 307 adults and children (range 1 to 51 patients per recruiter) with acute infective conjunctivitis to the trial. Participants were randomised to one of three groups: immediate antibiotics (chloramphenicol eye drops; $\mathrm{n}=104$ ), no antibiotics (controls; $n=94)$, and delayed antibiotics $(n=109)$. Two hundred and fifty patients completed diaries for outcomes (response rate $81 \%$; fig 1 ).

\section{Baseline characteristics}

The groups had similar characteristics at baseline (table 1). Response rates did not differ significantly between the groups: no antibiotics 76/94 (81\%), immediate antibiotics 84/104 (82\%), and delayed antibiotics $89 / 109(82 \% ; \mathrm{P}=0.9)$. Although responders were older than non-responders (mean (SD) 29.5 (28.4) years $v 18.3$ (18.7) years) and had lower deprivation scores (12.7 (9.8) v 15.9 (11.5)), including these variables in the models did not alter the estimates of effectiveness.

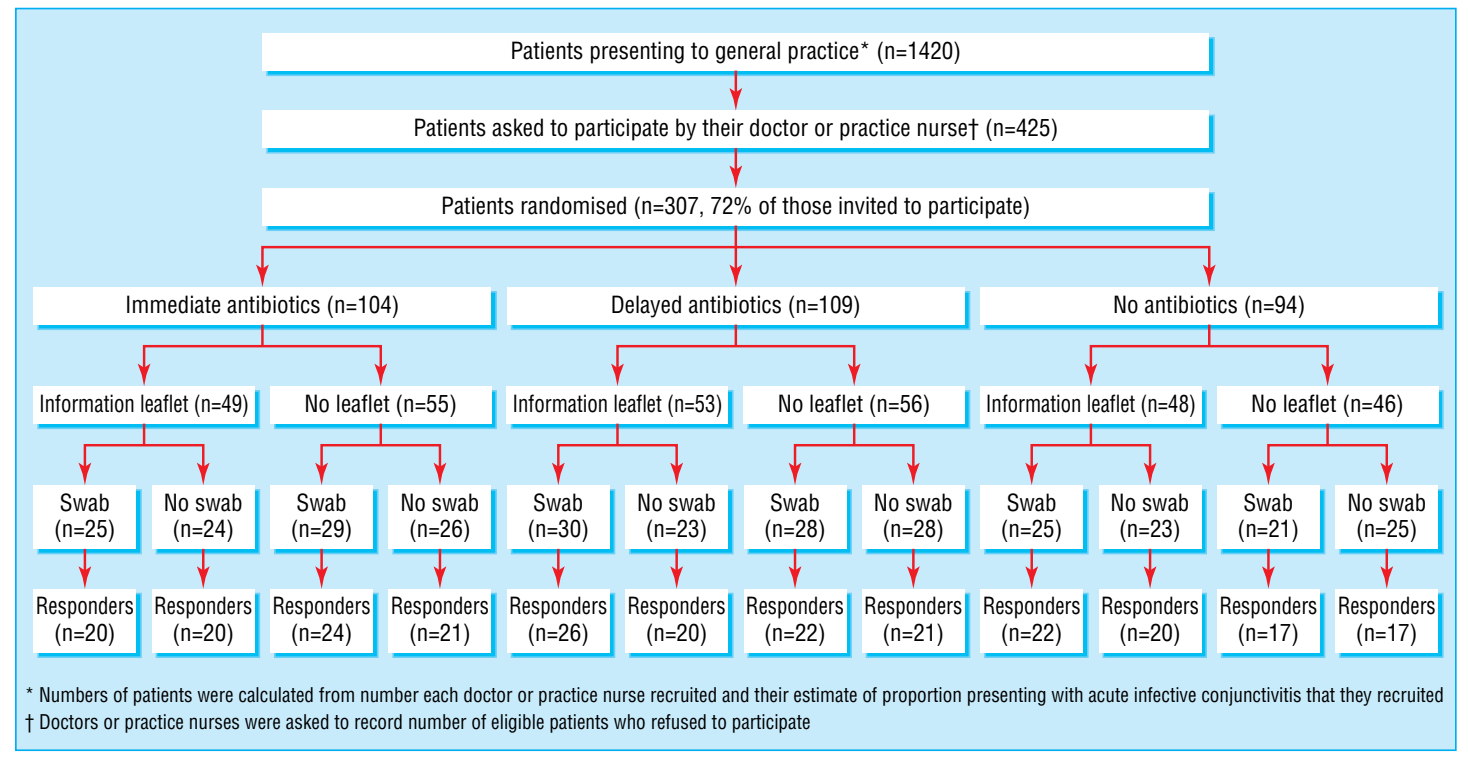

Fig 1 Flow of participants through trial 
Table1 Baseline characteristics of participants with acute infective conjunctivitis randomised to immediate antibiotic (chloramphenicol) eye drops, no antibiotics (controls), or delayed antibiotics. Values are numbers (percentages) unless stated otherwise

\begin{tabular}{|c|c|c|c|}
\hline Characteristics & $\begin{array}{l}\text { No antibiotics } \\
(n=94)\end{array}$ & $\begin{array}{c}\text { Immediate } \\
\text { antibiotics }(n=104)\end{array}$ & $\begin{array}{l}\text { Delayed } \\
\text { antibiotics } \\
(\mathrm{n}=109)\end{array}$ \\
\hline Mean (SD) age (years) & $27.2(27.6)$ & $27.2(25.1)$ & $28.2(25.9)$ \\
\hline $\begin{array}{l}\text { Participants aged }<12 \\
\text { years }\end{array}$ & 46/94 (49) & 43/104 (41) & 49/109 (45) \\
\hline Males & $39 / 94 \quad(42)$ & 45/104 (43) & 49/109 (45) \\
\hline $\begin{array}{l}\text { Males aged }<12 \text { years (\% } \\
\text { of all children) }\end{array}$ & $26 / 49$ (53) & $25 / 43 \quad(58)$ & $26 / 46(57)$ \\
\hline $\begin{array}{l}\text { Males aged }>12 \text { years (\% } \\
\text { of all adults) }\end{array}$ & $13 / 45$ (29) & 20/61 (33) & 23/63 (37) \\
\hline \multicolumn{4}{|l|}{ Deprivation score*: } \\
\hline Mean (SD) & $14.4(11.6)$ & $12.6(10.2)$ & $13.1(8.7)$ \\
\hline Median (range) & $10.8(1.5-44.7)$ & $8.5(1.9-46.3)$ & $10.7(1.5-45.2)$ \\
\hline \multicolumn{4}{|l|}{ Clinical features†: } \\
\hline Unilateral & 42/93 (45) & $59 / 103$ (57) & $62 / 109$ (57) \\
\hline $\begin{array}{l}\text { Moderate to severe } \\
\text { conjunctival injection }\end{array}$ & $37 / 92$ (40) & 43/101 (43) & 47/108 (44) \\
\hline Discharge & 74/91 (81) & $84 / 102$ (82) & $86 / 108$ (80) \\
\hline \multicolumn{4}{|l|}{$\begin{array}{l}\text { Duration of symptoms } \\
\text { (days): }\end{array}$} \\
\hline $0-2$ & $56 / 94 \quad(60)$ & 70/104 (67) & 72/108 (67) \\
\hline $3-6$ & $27 / 94 \quad(29)$ & 29/104 (28) & $25 / 108$ (23) \\
\hline $7-14$ & $11 / 94$ (12) & $5 / 104 \quad(5)$ & 11/108 (10) \\
\hline
\end{tabular}

*Index of multiple deprivation.

†Denominators vary from number recruited owing to small number of incomplete clinical signs sheets from general practitioners.

\section{Antibiotic use}

During the episode of conjunctivitis, antibiotics were used by $99 \%$ of the immediate group, $53 \%$ of the delayed group, and $30 \%$ of the no antibiotic group: immediate antibiotics versus no antibiotics, odds ratio 185.4 (95\% confidence interval 23.9 to 1439.2); delayed antibiotics versus no antibiotics 2.9 (1.4 to 5.7). As this was a pragmatic trial, patients in the no antibiotic group were free to consult their general practitioner and the general practitioners were free to treat patients in subsequent consultations as they thought appropriate.

\section{Main outcome measures}

Factor analysis indicated that all seven symptoms were part of one factor (Cronbach's $\alpha$ 0.84) and thus all were used to calculate the outcomes.

The average score for severity of symptoms on days 1-3 did not differ significantly between the groups (table 2). Duration of moderate symptoms was shorter in the immediate and delayed antibiotic groups than in the control group: controls 4.8 days, immediate antibiotics 3.3 days (risk ratio $0.7,95 \%$ confidence

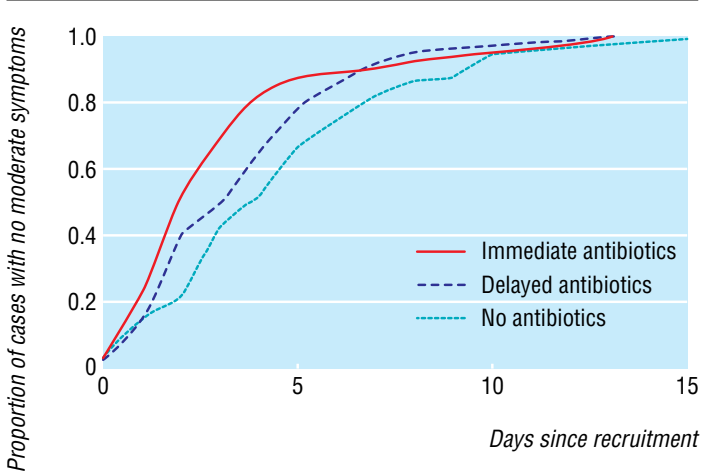

Fig 2 Resolution of moderate symptoms in patients with acute infective conjunctivitis assigned to immediate antibiotics (chloramphenicol eye drops), no antibiotics (controls), or delayed antibiotics

interval 0.6 to 0.8$)$, and delayed antibiotics 3.9 days $(0.8,0.7$ to 0.9 ; table 2). Figure 2 shows the resolution of moderate symptoms.

The immediate antibiotic group were more likely than controls to believe that antibiotics were effective (odds ratio 2.4, 1.1 to 5.0: number needed to treat 5) and more likely to state their intention to reattend for eye infections $(3.2,1.6$ to 6.4 : number needed to treat 4 ). The delayed antibiotic group was not significantly different from the controls (table 2).

A patient information leaflet or obtaining an eye swab did not significantly affect any outcomes (tables 3 and 4).

\section{Patient information leaflet and eye swab}

Participants completed diaries on concerns about their eye problem, how well their doctor dealt with their concerns, how satisfied they were with the consultation, the importance of seeing the doctor or nurse so that they could continue work or schooling, and satisfaction with the information they were given (tables 5-7). The answers were not related to the antibiotic group to which the patient had been randomised (table 5).

Satisfaction with the amount of information on eye infections was greater in those who received a patient information leaflet (odds ratio 2.4, 1.3 to 4.5). The leaflet was also associated with an increase in the patient's perception that the doctor dealt with their concerns extremely or very well $(1.9,1.0$ to 3.7$)$ and satisfaction with the consultation $(1.9,1.0$ to 3.7 ; table $6)$.

Obtaining an eye swab increased patients' concerns and worries about conjunctivitis $(1.7,1.0$ to 3.0$)$ possibly due to increased uncertainty about the diagnosis (table 7 ).

Table 2 Main outcomes by antibiotic group for responders (adjusted for patient information leaflet and eye swab)

\begin{tabular}{|c|c|c|c|c|c|c|c|}
\hline Outcome & No antibiotics $(n=76)$ & $\begin{array}{c}\text { Immediate } \\
\text { antibiotics ( } n=85)\end{array}$ & $\begin{array}{c}\text { Difference } \\
\text { (immediate-no } \\
\text { antibiotics) }(95 \% \mathrm{CI})\end{array}$ & $P$ value & $\begin{array}{c}\text { Delayed } \\
\text { antibiotics ( } \mathrm{n}=89 \text { ) }\end{array}$ & $\begin{array}{l}\text { Difference (delayed-no } \\
\text { antibiotics) (95\% Cl) }\end{array}$ & $P$ value \\
\hline Mean (SD) symptom score* & $2.1(0.9)$ & $1.9(0.9)$ & $-0.2(-0.5$ to 0.1$)$ & 0.2 & $2.0(1.0)$ & $-0.1(-0.4$ to 0.2$)$ & 0.4 \\
\hline $\begin{array}{l}\text { Mean (SD) duration of moderate } \\
\text { symptoms (days) }\end{array}$ & 4.8 (3.2) & $3.3(2.8)$ & $0.7 \dagger(0.6$ to 0.8$)$ & 0.001 & $3.9(2.5)$ & $0.8 \dagger(0.7$ to 0.9$)$ & 0.002 \\
\hline $\begin{array}{l}\text { No (\%) who believe antibiotics are } \\
\text { extremely or very effective for eye } \\
\text { infections }\end{array}$ & $23 / 49(47)$ & $47 / 70(67)$ & $2.4 \ddagger(1.1$ to 5.0$)$ & 0.03 & $36 / 65(55)$ & $1.4 \ddagger(0.7$ to 3.0$)$ & 0.4 \\
\hline $\begin{array}{l}\text { No (\%) who are extremely or very } \\
\text { likely to reattend for future eye } \\
\text { infections }\end{array}$ & $26 / 65(40)$ & $49 / 72(68)$ & $3.2 \ddagger(1.6$ to 6.4$)$ & 0.001 & $34 / 84(41)$ & $1.0 \ddagger(0.5$ to 2.0$)$ & 1.0 \\
\hline
\end{tabular}

* Scored on days 1-3 after consultation for acute infective conjunctivitis.

†Rate ratio.

$\ddagger 0$ dds ratio. 
Table 3 Main outcomes by patient information leaflet for responders (adjusted for antibiotic group and eye swab)

\begin{tabular}{|c|c|c|c|c|}
\hline Outcome & $\begin{array}{l}\text { No information } \\
\text { leaflet }(n=119)\end{array}$ & $\begin{array}{c}\text { Information } \\
\text { leaflet }(n=122)\end{array}$ & $\begin{array}{l}\text { Difference } \\
\text { (leaflet-no } \\
\text { leaflet) }(95 \% \\
\text { CI) } \\
\end{array}$ & $P$ value \\
\hline $\begin{array}{l}\text { Mean (SD) symptom } \\
\text { score }^{*}\end{array}$ & $1.9(1.0)$ & $2.0(1.0)$ & $\begin{array}{c}0.1 \\
(-0.2 \text { to } 0.3)\end{array}$ & 0.6 \\
\hline $\begin{array}{l}\text { Mean (SD) duration of } \\
\text { moderate symptoms } \\
\text { (days) }\end{array}$ & $3.9(2.9)$ & $4.1(3.0)$ & $\begin{array}{c}1.0 \dagger \\
(0.8 \text { to } 1.3)\end{array}$ & 0.9 \\
\hline $\begin{array}{l}\text { No (\%) who believe } \\
\text { antibiotics are } \\
\text { extremely or very } \\
\text { effective for eye } \\
\text { infections }\end{array}$ & $51 / 88 \quad(58)$ & $55 / 96$ (57) & $\begin{array}{c}1.0 \ddagger \\
(0.9 \text { to } 1.2)\end{array}$ & 0.8 \\
\hline $\begin{array}{l}\text { No (\%) extremely or very } \\
\text { likely to reattend for } \\
\text { future eye infections }\end{array}$ & $57 / 107$ (53) & $52 / 114$ (46) & $\begin{array}{c}0.8 \ddagger \\
(0.4 \text { to } 1.3)\end{array}$ & 0.3 \\
\hline
\end{tabular}

${ }^{*}$ Scored on days 1-3 after consultation for acute infective conjunctivitis.

†Rate ratio

$\ddagger 0$ dds ratio.

\section{Eye swab analysis}

Of 158 participants randomised to an eye swab, results were unavailable for 20. Swab analysis was undertaken using a modified Cagel and Abshire technique. ${ }^{19}$ Significant bacterial growth was detected in $69(50 \%)$ swabs. The main organisms were Haemophilus influenzae (26 swabs, 38\%), Streptococcus pneumoniae (16 swabs, 23\%), and Staphylococcus aureus (11, 16\%). No significant difference was found in outcome measures between those with and without bacterial growth-for example, in the immediate antibiotic group the mean duration of moderate symptoms was 3.5 days (95\% confidence interval 2.2 to 4.8$)$ if the swab result was positive and 3.5 days (2.0 to 5.0) if the swab result was negative $(\mathrm{P}=1.0)$.

Table 4 Main outcomes by eye swab for responders (adjusted for antibiotic group and patient information leaflet)

\begin{tabular}{|c|c|c|c|c|}
\hline Outcome & $\begin{array}{l}\text { No eye } \\
\text { swab } \\
(n=117)\end{array}$ & $\begin{array}{c}\text { Eye swab } \\
(\mathrm{n}=127)\end{array}$ & $\begin{array}{l}\text { Difference (eye } \\
\text { swab-no eye } \\
\text { swab) (95\% Cl) }\end{array}$ & $P$ value \\
\hline Mean (SD) symptom score ${ }^{*}$ & $1.9(0.9)$ & $2.1(1.0)$ & $0.2(-0.1$ to 0.4$)$ & 0.2 \\
\hline $\begin{array}{l}\text { Mean (SD) duration of } \\
\text { moderate symptoms (days) }\end{array}$ & $3.8(2.9)$ & $4.2(3.0)$ & $1.1 \dagger(1.0$ to 1.3$)$ & 0.1 \\
\hline $\begin{array}{l}\text { No (\%) who believe antibiotics } \\
\text { are extremely or very } \\
\text { effective for eye infections }\end{array}$ & $56 / 95(59)$ & $50 / 89(56)$ & $0.9 \neq(0.5$ to 1.6$)$ & 0.6 \\
\hline $\begin{array}{l}\text { No (\%) extremely or very } \\
\text { likely to reattend for future } \\
\text { eye infections }\end{array}$ & $53 / 109$ (49) & $56 / 112(50)$ & $1.1 \neq(0.6$ to 1.9$)$ & 0.7 \\
\hline
\end{tabular}

Table 6 Responses to diary questions by patient information leaflet (adjusted for antibiotic group and eye swab). Values are numbers (percentages) unless stated otherwise

\begin{tabular}{|c|c|c|c|c|}
\hline $\begin{array}{l}\text { Response to diary } \\
\text { question }\end{array}$ & $\begin{array}{c}\text { No information } \\
\text { leaflet }\end{array}$ & $\begin{array}{l}\text { Information } \\
\text { leaflet }\end{array}$ & $\begin{array}{l}\text { Odds ratio } \\
(95 \% \mathrm{Cl})\end{array}$ & $P$ value \\
\hline $\begin{array}{l}\text { Extremely, very, or } \\
\text { moderately worried } \\
\text { about eye infection }\end{array}$ & $38 / 106$ (36) & $51 / 120(43)$ & 1.3 (0.8 to 2.3) & 0.33 \\
\hline $\begin{array}{l}\text { Doctor dealt with worries } \\
\text { or concerns extremely } \\
\text { or very well }\end{array}$ & 79/107 (74) & $101 / 120$ (84) & 1.9 (1.0 to 3.7$)$ & 0.05 \\
\hline $\begin{array}{l}\text { Extremely or very } \\
\text { satisfied with } \\
\text { consultation }\end{array}$ & $80 / 108$ (74) & $101 / 120$ (84) & 1.9 (1.0 to 3.7$)$ & 0.05 \\
\hline $\begin{array}{l}\text { Believe that seeing doctor } \\
\text { or nurse is extremely } \\
\text { or very important for } \\
\text { work, preschool, or } \\
\text { school attendance }\end{array}$ & $52 / 102$ (51) & $59 / 118$ (50) & 1.0 (0.6 to 1.7) & 1.0 \\
\hline $\begin{array}{l}\text { Extremely or very } \\
\text { satisfied with amount } \\
\text { of information on eye } \\
\text { infections }\end{array}$ & $70 / 108$ (65) & $98 / 120(82)$ & 2.4 (1.3 to 4.5$)$ & 0.004 \\
\hline
\end{tabular}

\section{Reattendance and complications}

Overall 57 of the 307 (19\%) participants reattended for conjunctivitis in the year after recruitment, $26(9 \%)$ within two weeks. Those in the delayed antibiotic group were less likely to reattend within two weeks than those in the control group (odds ratio 0.3, $95 \%$ confidence interval 0.1 to 1.0 ), but no significant difference was found between the immediate antibiotic group and the controls $(0.7,0.3$ to 1.6$)$.

One patient in the immediate antibiotic group developed orbital cellulites and was admitted to hospital 11 days after recruitment. Unlike the other participants, this patient had extremely high symptom scores on the basis of data recorded in the diary.

\section{Recruitment}

No difference was found between high recruiters (general practitioners or practice nurses who recruited more than $70 \%$ of cases encountered) and low recruiters in severity of presenting symptoms, sex of participants, or proportion of children participating, but higher recruiters recruited older participants (mean age 31.6 $v 24.6$ years) and participants with lower deprivation scores (index of multiple deprivation $11.4 v 14.8$ ). Recruitment status of the patient did not affect outcome measures however.

\section{Discussion}

Different prescribing strategies using chloramphenicol eye drops for acute infective conjunctivitis (immediate antibiotics, no

Table 5 Responses to diary questions by antibiotic group (adjusted for eye swab and patient information leaflet). Values are numbers (percentages) unless stated otherwise

\begin{tabular}{|c|c|c|c|c|c|c|c|}
\hline Response to diary question & No antibiotics & Immediate antibiotics & Odds ratio $(95 \% \mathrm{CI})$ & $P$ value & Delayed antibiotics & Odds ratio $(95 \% \mathrm{Cl})$ & $P$ value \\
\hline $\begin{array}{l}\text { Extremely, very, or moderately } \\
\text { worried about eye infection }\end{array}$ & $30 / 70(43)$ & $29 / 73(40)$ & 0.9 (0.5 to 1.8$)$ & 0.75 & $30 / 83(36)$ & 0.7 (0.4 to 1.4$)$ & 0.3 \\
\hline $\begin{array}{l}\text { Doctor dealt with worries or } \\
\text { concerns extremely or very well }\end{array}$ & $54 / 71(76)$ & $59 / 73(81)$ & 1.4 (0.6 to 3.1$)$ & 0.43 & $67 / 83(81)$ & 1.3 (0.6 to 2.9$)$ & 0.48 \\
\hline $\begin{array}{l}\text { Extremely or very satisfied with } \\
\text { consultation }\end{array}$ & $53 / 71$ (75) & $61 / 73(84)$ & 1.8 (0.8 to 4.1$)$ & 0.2 & $67 / 84(80)$ & 1.4 (0.6 to 2.9$)$ & 0.4 \\
\hline $\begin{array}{l}\text { Believe that seeing doctor or nurse } \\
\text { is extremely or very important for } \\
\text { work, preschool, or school } \\
\text { attendance }\end{array}$ & $34 / 67 \quad(51)$ & $44 / 71 \quad(62)$ & 1.6 (0.8 to 3.1$)$ & 0.1 & $33 / 82(40)$ & 0.7 (0.3 to 1.3$)$ & 0.2 \\
\hline $\begin{array}{l}\text { Extremely or very satisfied with } \\
\text { amount of information on eye } \\
\text { infections }\end{array}$ & $55 / 71(78)$ & $55 / 73(75)$ & 0.9 (0.4 to 2.0) & 0.9 & $58 / 84(69)$ & 0.6 (0.3 to 1.3$)$ & 0.24 \\
\hline
\end{tabular}


Table 7 Responses to diary questions by eye swab (adjusted for antibiotic group and patient information leaflet). Values are numbers (percentages) unless stated otherwise

\begin{tabular}{|c|c|c|c|c|}
\hline Response to diary question & No eye swab & Eye swab & $\begin{array}{l}\text { Odds ratio }(95 \% \\
\text { CI) }\end{array}$ & $P$ value \\
\hline $\begin{array}{l}\text { Extremely, very, or } \\
\text { moderately worried about } \\
\text { eye infection }\end{array}$ & $37 / 112$ (33) & $52 / 114$ (46) & 1.7 (1.0 to 3.0$)$ & 0.05 \\
\hline $\begin{array}{l}\text { Doctor dealt with worries or } \\
\text { concerns extremely or } \\
\text { very well }\end{array}$ & $88 / 112$ (79) & $92 / 115$ (80) & 1.1 (0.6 to 2.1) & 0.83 \\
\hline $\begin{array}{l}\text { Extremely or very satisfied } \\
\text { with consultation }\end{array}$ & $90 / 113$ (80) & $91 / 115$ (79) & $1.0(0.5$ to 1.8$)$ & 0.9 \\
\hline $\begin{array}{l}\text { Believe that seeing doctor } \\
\text { or nurse is extremely or } \\
\text { very important for work, } \\
\text { preschool, or school } \\
\text { attendance }\end{array}$ & $55 / 108$ & $56 / 108(50)$ & $1.0(0.6$ to 1.7$)$ & 1.0 \\
\hline $\begin{array}{l}\text { Extremely or very satisfied } \\
\text { with amount of } \\
\text { information on eye } \\
\text { infections }\end{array}$ & $81 / 113$ (72) & $87 / 115$ (76) & 1.2 (0.7 to 2.3) & 0.5 \\
\hline
\end{tabular}

antibiotics, delayed antibiotics) did not affect symptom severity in the three days after consulting, but duration of moderate symptoms was less in the immediate and delayed antibiotic groups. Compared with no initial offer of antibiotics, antibiotic use, belief in the effectiveness of antibiotics, and intention to reattend for eye infections were higher in the immediate antibiotic group. A patient information leaflet or eye swab had no effect on the main outcome measures.

On average symptoms were scored as slight to moderate, consistent with our qualitative research ${ }^{16}$ where patients described symptoms as "minor" or "niggly." However, antibiotics were used by $53 \%$ of the delayed antibiotic group and $30 \%$ of the no antibiotic group. This was probably related to a belief in the need for antibiotics to clear the infection despite symptoms being mild. ${ }^{16}$ Whatever the reasons, no initial offer of antibiotics resulted in significant use of antibiotics.

In our study population the difference between the immediate and no antibiotic groups was one and a half days of moderate symptoms-half a day for the delayed antibiotic group. The proportion of patients cured converged, so by day 8 there was no significant difference between the groups (fig 2). This varies with the results of Rose et al's study, ${ }^{11}$ which found a consistent 0.3 day difference in symptoms between chloramphenicol and placebo groups for days 2-7 after consultation. Plausible explanations are a greater placebo effect, although this is unlikely as estimates from our previous open trials ${ }^{17} 18$ (using identical methodology) were similar to blinded trials; Rose et $\mathrm{al}^{11}$ underestimated the effect of drops (our study estimates are closer to the Cochrane review ${ }^{43}$ ); different outcome measures were used (Rose et al did not measure duration of moderate symptoms ${ }^{11}$ ); and a non-specific mechanical effect of drops may provide lubrication and help flush out pathogens (both arms in Rose et al's study had drops ${ }^{11}$ ).

It might be worth prescribing antibiotics for the one to two days reduction in moderately bad symptoms (immediate antibiotics compared with no antibiotics); however is it worth prescribing immediate antibiotics to all when the benefit compared with delayed antibiotics is likely to be a half day's reduction in moderate symptoms? It may well depend on individual patients' circumstances (for example, whether children can attend day care). Preschools may be unwilling to allow children with sticky eyes to attend-an issue highlighted by Rose et al's study. ${ }^{11}$

Immediate prescribing of antibiotics seems to medicalise patients with conjunctivitis, as found with some respiratory tract infections. ${ }^{14}{ }^{17}$ Patients assigned to immediate antibiotics were more likely to indicate that they would reattend for eye infections than those assigned to no or delayed antibiotics.

Delayed prescribing gives the opportunity to discuss the clinical course of conjunctivitis with patients. Our qualitative research ${ }^{16}$ indicated that patients' lack of awareness of the self limiting nature of conjunctivitis was an important reason for attending for antibiotics. It also showed that patients were happy with delayed prescribing and were comfortable about deciding whether to start antibiotics.

The recent decision to make topical chloramphenicol available over the counter in the United Kingdom (www.mhra.gov.uk) may increase the use of topical antibiotics in the community independent of general practitioner management strategies.

A patient information leaflet and obtaining an eye swab did not affect the main outcome measures. However, patients' responses in their diaries showed that an information leaflet may increase satisfaction with the consultation, the amount of information received, and the patient's perception that the doctor dealt with their concerns well. Conversely, obtaining an eye swab may increase patients' worries about their eye infection.

\section{Strengths and limitations of the study}

The pragmatic open trial design of our study enabled assessment of prescribing strategies in a setting that closely resembles normal general practice-assessment not only of symptom resolution but also of patients' responses to different strategies, belief in the effectiveness of antibiotics, use of antibiotics, and intention to reattend for eye infections.

Standard advice packages were used to allow the general practitioners to support each strategy in a similar way and thus minimise any placebo effect, as used successfully in previous trials. $^{14} 1718$

Selective overall recruitment could limit generalisability. Not every patient who consulted with conjunctivitis was recruited owing to lack of time, exclusion criteria (for example, children aged less than 1 year or chronic eye conditions), and patients refusing to participate in the trial. Patients from high recruiters differed in age and deprivation score from those of low recruiters, however recruitment status of the patient did not predict any outcome or affect the estimates of effectiveness of interventions. Although respondents were older and had lower deprivation scores than non-respondents, neither of these altered the effect size.

The delayed antibiotic strategy involved participants returning to the surgery for their prescription. This may have reduced antibiotic use compared with a strategy of providing the prescription in the consultation and advising a delay in using the drug.

\section{Conclusion}

The delayed prescribing approach may be the best approach. Compared with no initial offer of antibiotics delayed prescribing had the advantage of reduced antibiotic use (almost 50\%), no evidence of medicalisation, similar symptom control to immediate prescribing, and reduced reattendance for eye infections.

We thank the trial steering committee for advice and support, the general practitioners and practice nurses for recruiting participants, Andy Tuck for laboratory support, and the participants.

Contributors: HAE and PSL conceived and drafted the study. PWFS provided statistical advice and support. All authors commented on drafts of the paper. HAE was principal investigator and responsible for the day to day running of the trial, statistical analysis, and report writing. She is guarantor. 


\section{Research}

Funding: The research was funded by the Medical Research Council as part of a clinical training fellowship awarded to HAE. The authors' work was independent of the funder.

Competing interests: None declared.

Ethical approval: This study was approved by Southampton, Portsmouth, Salisbury, and Dorset local research ethics committees.

1 Sheldrick JH, Wilson AD, Vernon SA. Management of ophthalmic disease in genera practice. Brit J Gen Pract 1993;43:462.

2 McDonnell PJ. How do general practitioners manage eye disease in the community? Brit J Ophthalmol 1988;72:736.

3 McCormick A, Fleming D, Charlton J. Morbidity statistics from general practice. Fourth national study 1991-2. London: HMSO, 1995.

Sheikh A, Hurwitz B, Cave J. Antibiotics for acute bacterial conjunctivitis. Cochrane Database Syst Rev 2000;(2):CD001211.

5 Rietveld RP, van Weert HCPM, Riet GT, Bindels PJE. Diagnostic impact of signs and symptoms in acute infective conjunctivitis: systematic literature search. $B M J$ 2003;327:789.

6 Bron AJ, Leber G, Rizk SN, Baig H, Elkington AR, Kirkby GR, et al. Ofloxacin compared with chloramphenicol in the management of external ocular infection. Brit J Ophthalmol 1991;75:675-9

\section{What is already known on this topic}

Topical antibiotics are usually prescribed for conjunctivitis but evidence on their effectiveness is mixed

\section{What this study adds}

Delaying antibiotics for conjunctivitis in primary care was associated with reduced antibiotic use, no evidence of medicalisation, and similar severity and duration of symptoms to immediate prescribing

No initial offer of antibiotics for acute infective conjunctivitis still resulted in significant antibiotic use $(30 \%)$

Compared with no antibiotics, delayed prescribing was associated with reduced reattendance for eye infections
7 Gigliotti F, Williams WT, Hayden FG, Hendley JO. Etiology of acute conjunctivitis in children J Paediatr 1981:98:531.

8 Little P, Gould C, Williamson I, Warner G, Gantley M, Kinmonth AL. Reattendance and complications in a randomised trial of prescribing strategies for sore throat: the medicalising effect of prescribing antibiotics. BMJ 1997;315:350-2.

9 Leibovici L, Lievre M. Medicalisation: peering from inside medicine. $B M$ J 2002;324:866.

10 Everitt H, Little P. How do GPs diagnose and manage acute infective conjunctivitis? A GP survey. Fam Pract 2002;19:658-60.

11 Rose PW, Harnden A, Brueggemann AB, Perera R, Sheikh A, Crook D, et al. Chloramphenicol treatment for acute infective conjunctivitis in children in primary care: a randomised double-blind placebo-controlled trial. Lancet 2005;366:37-43.

12 Rietveld RP, Riet GT, Bindels PJE, Bink D, Sloos JH, van Weert HCPM. The treatment of acute infectious conjunctivitis with fusidic acid: a randomised controlled trial. Brit Gen Pract 2005;55:924-30.

13 Sheikh A, Hurwitz B. Topical antibiotics for acute bacterial conjunctivitis: Cochrane systematic review and meta-analysis update. Brit J Gen Pract 2005;55:962-4.

14 Little P, Williamson I, Warner G, Gould C, Gantley M, Kinmonth AL. Open randomised controlled trial of prescribing strategies in managing sore throat. BMJ 1997;314:722-7.

15 Sharland M, Kendall H, Yeates D, Randall A, Hughes G, Glasziuo P, et al. Antibiotic prescribing in general practice and hospital admissions for peritonsillar abscess, mastoiditis, and rheumatic fever in children: time trend analysis. BMJ 2005;331:328-9.

16 Everitt H, Kumar S, Little P. A qualitative study of patients' perceptions of acute infective conjunctivitis. Brit J Gen Pract 2003;53:36-41.

17 Little P. Pragmatic randomised controlled trial of two prescribing strategies for childhood acute otitis media. BMJ 2001;322:336-42.

18 Little P, Rumsby K, Kelly J, Watson L, Moore M, Warner G, et al. Information leaflet and antibiotic prescribing strategies for acute lower respiratory tract infection: a randomized controlled trial.JAMA 2005;293:3029-35.

19 Cagle GD, Abshire RL. Quantitative ocular bacteriology: a method for the enumeration and identification of bacteria from the skin-lash margin and conjunctiva. Invest Ophthalmol Vis Sci 1981;20:751-7.

(Accepted 7 June 2006)

doi 10.1136/bmj.38891.551088.7C

Primary Medical Care, University of Southampton, Aldermoor Health Centre, Southampton SO16 5ST

Hazel A Everitt MRC research training fellow

Paul S Little professor of primary care research

Southampton Statistical Sciences Research Institute, University of Southampton Peter W F Smith professor of social statistics

Correspondence to: H A Everitt hae1@soton.ac.uk 